\title{
Practical measures of cognitive function and promotion of their performance in the context of research
}

\author{
Mariusz Gujski ${ }^{1}$, Tomasz Juńczyk ${ }^{2}$, Jaroslaw Pinkas ${ }^{3}$, Alfred Owoc ${ }^{4}$, Iwona Bojar \\ ${ }^{1}$ Department of Prevention of Environmental Hazards and Allergology, Medical University, Warsaw, Poland \\ ${ }^{2}$ Faculty of Educational Studies, Adam Mickiewicz University, Poznan, Poland \\ ${ }^{3}$ School of Public Health, Medical Centre of Postgraduate Education, Warsaw, Poland \\ ${ }^{4}$ Centre for Public Health and Health Promotion, Institute of Rural Health, Lublin, Poland \\ ${ }^{5}$ Department for Woman Health, Institute of Rural Health, Lublin, Poland
}

Gujski M, Juńczyk T, Pinkas J, Owoc A, Bojar I. Practical measures of cognitive function and promotion of their performance in the context of research. Ann Agric Environ Med. 2016; 23(3): 399-402. doi: 10.5604/12321966.1219176

\begin{abstract}
Ibstract
The aging of the population generates a number of very interesting research questions in the fields of medicine, psychology, sociology, demography, and many others. One of the issues subject to both intensive research by scientists and exploration by practitioners is associated with cognitive functions. The article presents current knowledge regarding practical actions in the field of promoting cognitive function using diagnostic programmes and training using modern technologies. An important aspect presented in this study is also related to the welfare of the maintenance or improvement of cognitive function. Information and communication technologies will contribute to the dissemination of computerized cognitive training, also personalized.
\end{abstract}

Key words

cognitive function, cognitive reserve, prevention, training programmes

\section{INTRODUCTION}

The change in the age structure of Europe is already a fact. Predictions related to the number of people over 65 years of age in the coming decades indicate that in Poland they could constitute more than $1 / 3$ of the population [1]. This phenomenon generates a number of very interesting research questions in the fields of medicine, psychology, sociology, demography, and many others. It also inspires practitioners and the business sector to create new, innovative services dedicated to people over the of age of 65 . One of the issues subject to intensive research by both scientists and practitioners is associated with cognitive functions. As indicated in the vast literature available, in the population aged $65+$ the occurrence of cognitive impairment is highly likely [2]. Thus, practitioners are looking for techniques that could significantly delay the emergence of cognitive deficits, and which would be accessible, easy to use and inexpensive, and access to them could greatly benefit a significant part of society.

Cognitive impairment associated with aging - 'cognitive reserve'. Cognitive ability decreases with age, especially regarding processing speed and psychomotor speed. Some skills, however, can remain at a stable, or even up to a certain age can improve, for example, verbal memory [3]. There is a variety of cognitive changes linked to aging [4]. Understanding this aspect of cognitive aging (on the socalled cognitive reserve) can lead to the search for ways to enhance cognitive function and prevent their deficits $[5,6]$.

Address for correspondence: Iwona Bojar, Department for Woman Health, Institute of Rural Health in Lublin, Jaczewskiego 2, 20-090 Lublin, Poland

E-mail: iwonabojar75@gmail.com

Received: 08 August 2016; accepted: 24 August 2016
Currently available literature shows that within the population there are individual differences in cognitive processing and neurological brain function, which are of particular importance in the context of prevention of cognitive disorders or minimizing the cognitive deficits in patients diagnosed with mild cognitive impairment (MCI) and Alzheimer's disease. Evidence for these differences include cases of people with similar head injuries, but result in completely different cognitive deficits. Stern, for an explanation of this phenomenon, proposed the concept of the so-called. 'Cognitive Reserve' (CR) [7]. 'This term refers to a set of mental skills and strategies needed to effectively address the complex cognitive tasks, despite the existence of the pathology of the brain. With the CR, even the presence of advanced neuropathological changes does not rule out dealing with difficult (complex or new) cognitive problems. Those with a high reserve of cognitive functioning better than those with low reserve - even when the severity of $\mathrm{AD}$ is typical of similar' [8]. The level of cognitive reserve is dependent on a number of variables related to life experiences, challenges undertaken, educational pastime, position, profession, social status, etc. Therefore, the cognitive activity of the individual is of great importance.

After the first suggestions that those with a higher level of education have a lower incidence of dementia, there have been studies suggesting that cognitive activity is associated with a reduced risk for cognitive impairment and dementia. Several prospective observational studies have reported that people who engage in mentally stimulating activities, such as learning to read, are less likely to develop dementia compared with those who do not engage in such activities. Older people who are cognitively active, can have a higher degree of neuropathological changes without symptoms showing the characteristics of dementia, compared with those who do not 
engage in cognitively stimulated activity. Broad action also includes activity and forms of recreation among the activities that maximize cognitive reserve. Studies have shown that interventions that could reduce the risk of cognitive disorders and slow cognitive deficits [9]. It has also been shown that although mental training can improve memory, reasoning and processing speed in the elderly [9], one cannot generalize their impact on all the cognitive domains, and have no effect on daily functioning [10]. It should also be noted that older people with well-established memory impairment may be less able to capture the benefits of memory training, compared to those without such dysfunction [11].

The results of cohort studies published in BMC Public Health in 2015, shows that a higher level of involvement in physical, social and intellectual activity improves cognitive abilities, and at the same time reduces the probability of incident dementia [12], thus confirming the concept of 'cognitive reserve'. Implementation of tasks that require the involvement of cognitive function works not for prevention but also brings significant benefits for people diagnosed with AD. Research by Treiner et al. shows that in the case of people who have dementia for less than a year, the lack of commitment to the cognitive tasks may lead to lower test scores in the MMSE of 3.9 points per year, while in people performing five stimulating exercise per week, the decline was 2.2 points [13].

It therefore appears that stimulating the development of cognitive reserve through intellectual exercise is one of the most effective forms of prevention of cognitive disorders, and delaying the increase in cognitive deficits. This justifies the need for professional development of the possibilities available in terms of the training task.

Diagnostic programmes and training to support cognitive function using modern technologies. In the area of software supporting cognitive function, the best known at the moment is Lumosity Brain Games \& Brain Training. The company (Lumos Labs, USA) has created several short games and exercises aimed at strengthening cognitive function, as specified by the manufacturer. In 2013, the software recorded 50 million users [14]. Another important player in the market is the platform HAPPYneuronPro (http:// www.scientificbraintrainingpro.com). The platform includes three training programmes, including one dedicated to people diagnosed with MCI (Mild Cognitive Impairment). Games like Lumosity consist of a series of exercises, divided thematically: Memory, Executive Functions, Attention, Language, and Visual Spatial Orientation. Trade studies indicate some of the most important cognitive vendors at the moment [15]:

1) Brain Resource - contains not only exercises in the area of cognitive function, but also those associated with a reduction in stress, building positive emotions and psychological resistance (www.mybrainsolutions.com).

2) CogState - focuses mainly on computerized diagnostic tests (www.cogstate.com).

3) Emotiv - uses a portable device for measuring EEG, connected with the personal computer and mobile devices to monitor brain function (www.emotiv.com).

4) Lumos Labs - creator of Lumosity.

5) NeuroSky - similar to Emotive combines software solutions with a portable device for monitoring EEG (www. neurosky.com).
A Polish counterpart - NEUROGRA (www.neurogra.pl) - contains four training programmes, including the socalled 'prevention of dementia'. A similar offer is available at www.brainmax.pl. Young researchers from the University School of Social Psychology in Warsaw are responsible for the laying out of the scientific programme. An extremely interesting project has been initiated by Deutsche Telekom, in cooperation with the University of East Anglia in the UK, UCL Dementia Research, and the Alzheimer's Research UK, who have created a game in which the main task is to gather information about the functioning or orientation of those participating in the visual-spatial game. On the basis of a huge number of collected data, a new model is created of the development of dementia, and widely available diagnostic tools (detailed information at: http://www.seaheroquest. $\mathrm{com} / \mathrm{pl})$.

Another direction for the use of ICT in support of people with cognitive impairment are themed games. An example is a game called 'Kitchen and Cooking', dedicated to patients with a diagnosis of MCI and $\mathrm{AD}$ (presentation of the game: https://www.youtube.com/watch?v=MzPnowouK7Y\&featu re=youtu.be). The game contains four scenarios associated with the preparation of a specific meal. Each has a similar list of tasks: choice of ingredients, planning of the order of tasks, performance on the tablet specific traffic (e.g. rotation of the object), starting 'cooking'. A survey of 20 users of the game, confirm that it is acceptable and 'playable' by people with cognitive impairment, but - as in the case of cognitive training - the issue of transfer of non-specifics remains questionable [16].

Intensive development of software for the diagnosis and maintenance of cognitive function will take place in the next few years. Experts estimate that in 2012 the market value was approx. $\$ 1$ trillion, and by 2020 will increase six-fold to approx. $\$ 6,000,000,000,000$. The development will concern both the software and portable devices to measure EEG and heart rate variability (HRV) [16].

Research on the effectiveness of computer training programmes. The available literature analyzing the effectiveness of task-based computer computer training programmes produces mixed results. The main area of discussion refers to the transfer of specific vs. non-specific trained skills. Transfer specific lies in the fact that the individual, through a process of learning, is better able to perform only the tasks of a similar nature as such as job training. This similarity may be manifested in the wording of instructions, appearance and character of a task, procedure, etc. The transfer of a specific character is thus limited and skills are not subject to broad generalizations. In the case of non-specific transfetransfe, we have to deal with the ability to apply previously acquired knowledge to solve problems of a different nature, unlike those practiced [17]. In the case of software to train specific cognitive transfer, this would mean faster and more effective execution of the same exercises ('better do what I practice'), and non-specific transfer, the transfer of practice from a situation training to a broader spectrum of untrained cognitive function. Some studies have confirmed the existence of the transfer of non-specific, such as in patients with a diagnosis of MCI for which the exercises are related to recognition. Pre-tests have demonstrated positive changes in the functions of memory [18]. Similarly, in a study published in 2014 involving 80 people aged 65-95s, applied 
exercises in verbal memory, working, and visual-spatial, simultaneously observed transfer to other cognitive functions [19]. At the same time, however, one can point out the study, the results suggest that in the case of programmes of this kind there is no transfer of non-specific [20]. According to the researchers, part of the transfer of specific has been proved, while the question of transfer of non-specific is still controversial [21].

Cognitive function and well-being. There are hundreds of studies on the impact of positive affect on cognitive processes, such as the search for creative solutions, abstract thinking, information processing, and flexibility in thinking [22]. In the search for a neurobiological explanation for these relationships, researchers turned to dopamine as a neurotransmitter, with a positive affect. Currently, there is already evidence that the dopaminergic system - ventral tegumental area (VTA) part of the brain - is active when people experience positive emotions. Activity is increasing after the presentation of rewarding stimuli [23]. Assuming that the neurobiological basis of the positive affect of dopamine, the researchers are subsequently seeking relationships between the activity of the dopaminergic system and cognitive processes. Research in this area are still being intensively implemented. It turns out that there are projections of the dopamine hippocampus and prefrontal cortex [24], which are responsible for such processes as the consolidation of information from short-term memory into long-term memory, spatial orientation, working memory, planning movements and activities. Therefore, since the positive affect activates dopamine, and this in turn affects the biological structures responsible for learning, it would be reasonable to state that an effective system of support cognitive should also include a positive emotionality. Confirmation of this thesis is the study of long-term stress, which, after all - from a psychological point of view - is a conglomeration of difficult emotions. In seniors in whom glucocorticoid levels increased over the years, the most significant changes have occurred in the hippocampus, resulting in significant problems with memory [25]. Conclusions from the studies show, among others, that the decline in cognitive function can be up to $30 \%$ higher in those individuals who have a high susceptibility to distress [26], and that negative social relationships may be a risk factor in the development of MCI [27]. At the same time, it appears that patients with a diagnosis of MCI and dementia cognitive performance associated with the reminder and recognition of objects, increases at a time when the task objects 'positive' [28]. In our opinion, these are very inspiring for further research results, indicating that the issue of cognitive impairment is a combination of issues, strictly medical, biological and psychological, resulting from the entity's system of interpreting onesself, the world and surrounding people. The creators of the modern tools to support older people seem to increasingly notice the complexity of the phenomenon. Perhaps that is why some tools, which we have referred to at the beginning of the article, also contain modules associated with the building of well-being and good mood. It appears that the effectiveness of cognitive exercises can be enhanced if the recipient is: 1) confident and psychologically ready for their use;

2) motivated and supported in their practice;

3) confident that performance will enable the learning of new skills, apply them in practice, and that they are beneficial.
From these, some indications may result for the development of training programsme, assuming that, like any learning process associated with cognitive function, they should be based on the mechanisms of motivation and support.

\section{CONCLUSIONS}

Information and communication technologies will contribute to the dissemination of computerized cognitive training, including those personalized. The undoubted advantage in this case is to increase the availability of a relatively cheap and user-friendly range of services. It is also noticeable that a more comprehensive approach to the subject is developing: from simple games, learners perform everyday life activities through training programmes which consistof a series of exercises purely cognitive, to comprehensive support programmes, including cognitive tasks, building a good mood or monitoring brain activity. Such a diversity allows offers to every potential customer - from people for whom prevention is important, to those after being diagnosed with dementia. For them, such offers can be an essential element of support in performing simple daily activities.

\section{REFERENCES}

1. Sytuacja demograficzna osób starszych i konsekwencje starzenia się ludności Polski w świetle prognozy na lata 2014-2050, Główny Urząd Statystyczny, Warszawa 2014

2. Mossakowska M, Więcek A, Błędowski P. Aspekty medyczne, psychologiczne, socjologiczne i ekonomiczne starzenia się ludzi w Polsce, Termedia Wydawnictwa Medyczne, Poznań 2012.

3. Salthouse TA. The processing-speed theory of adult age differences in cognition. Psychol Rev. 1996; 103: 403- 428.

4. Wilson RS, Beckett LA, Barnes LL, Schneider JA, Bach J, Evans DA, Bennett DA. Individual differences in rates of change in cognitive abilities of older persons. Psychol Aging. 2002; 17: 179 -193.

5. Schlaghecken F, Birak KS, Maylor EA. Age-related deficits in efficiency of low-level lateral inhibition. Front Hum Neurosci. 2012; 6: 102.

6. Depp CA, Jeste DV. Definitions and predictors of successful aging: A comprehensive review of larger quantitative studies. Am J Geriatr Psychiatry. 2006; 14: 6-20.

7. Stern Y. Cognitive reserve. Neuropsychologia. 2009; 47(10): 2015-2028.

8. Barczak A. Wykształcenie, aktywność umysłowa i socjalna jako czynniki protekcyjne otępienia. Aktualności Neurologiczne. 2014; 14(3): 161-166.

9. Acevedo A, Loewenstein DA. Nonpharmacological cognitive interventions in aging and dementia. J Geriatr Psychiatry Neurol. 2007; 20(4): 239-249.

10. Ball K, Berch DB, Helmers KF, Helmers KF, Jobe JB, Leveck MD, Marsiske M, Morris JN, Rebok GW, Smith DM, Tennstedt SL, Unverzagt FW, Willis SL. Advanced Cognitive Training for Independent and Vital Elderly Study Group. Effects of cognitive training interventions with older adults: a randomized controlled trial. JAMA. 2002;288(18): 2271-2281.

11. Unverzagt FW, Kasten L, Johnson KE, Rebok GW, Marsiske M, Koepke KM, Elias JW, Morris JN, Willis SL, Ball K, Rexroth DF, Smith DM, Wolinsky FD, Tennstedt SL. Effect of memory impairment on training outcomes in ACTIVE. J Int Neuropsychol Soc. 2007; 13(6): 953-960.

12. Marioni RE, Proust-Lima C, Amieva H, Brayne C, Matthews FE, Dartigues JF, Jacqmin-Gadda H. Social activity, cognitive decline and dementia risk: a 20 -year prospective cohort study. BMC public health. 2015; 15: 1089 .

13. Treiber KA, Carlson MC, Corcoran C, Norton MC, Breitner JCS, Piercy KW, DeBerard MS, Stein D, Foley B, Welsh-Bohmer KA, Frye A, Lyketsos CG, Tschanz JT. Cognitive Stimulation and Cognitive and Functional Decline in Alzheimer's Disease: The Cache County Dementia Progression Study. The Journals of Gerontology, Series B: Psychological Sciences and Social Sciences. 2011; 66(4): 416-425. 
14. http://blogs.wsj.com/digits/2013/11/05/small-brain-training-gamemaker-getting-bigger/

15. "The Digital Brain Health Market 2012-2020: Web-based, mobile and biometrics-based technology to assess, monitor and enhance cognition and brain functioning", http://sharpbrains.com/market-report/

16. Manera V, Petit PD, Derreumaux A, Orvieto I, Romagnoli M, Lyttle G, David R, Robert PH. Kitchen and cooking,' a serious game for mild cognitive impairment and Alzheimer's disease: a pilot study. Front Aging Neurosci. 2015; 7: 24.

17. Schunk D. Cognitive learning processes W: Learning theories: An educational perspective, (ed.) D. Schunk, Columbus, OH: Pearson 2004, p. 190-240.

18. Herrera C, Chambon C, Michel BF, Paban V, Alescio-Lautier B. Positive effects of computer-based cognitive training in adults with mild cognitive impairment. Neuropsychologia 2012; 50(8): 1871-1881.

19. Zinke K, Zeintl M, Rose NS, Putzmann J, Pydde A, Kliegel M, Eccles J. Working Memory Training and Transfer in Older Adults: Effects of Age, Baseline Performance, and Training Gains. Dev Psychol. 2014; 50(1): 304-315.

20. Richmond LL, Morrison AB, Chein JM, Olson IR, Duberstein P. Working Memory Training and Transfer in Older Adults. Psychol Aging. 2011; 26(4): 813-822.

21. Kowalczyk N, Brzezicka A, Kossut M. Zmiany neuroplastyczne w wyniku intensywnych treningów poznawczych: porównanie tradycyjnego podejścia i metod wykorzystujących gry komputerowe. Neuropsychiatria i Neuropsychologia. 2014; 9(3-4): 104-111.

22. Schiffrin HH, Falkenstern M. The Impact of Affect on Resource Development: Support for the Broaden-and-Build Model. North Am J Psychol. 2012; 14(3): 569-584.

23. Barajas MS. Thinking and Feeling: The Influence of Positive Emotion on Human Cognition. Hilltop Rev. 2015; 7: 1.

24. Czapiński J. (ed.), Psychologia pozytywna. Nauka o szczęściu, zdrowiu, sile i cnotach człowieka, Wydawnictwo Naukowe PWN, Warszawa 2012.

25. Sapolsky R. Dlaczego zebry nie mają wrzodów? Psychofizjologia stresu, Wydawnictwo Naukowe PWN, Warszawa 2010.

26. Wilson RS, Bennett DA, Mendes de Leon CF, Bienias JL, Morris MC, Evans DA. Distress proneness and cognitive decline in a population of older persons. Psychoneuroendocrinology. 2005; 30(1): 11-17.

27. Wilson RS, Boyle PA, James BD, Leurgans SE, Buchman AS, Bennett DA, Brown GG. Negative Social Interactions and Risk of Mild Cognitive Impairment in Old Age. Neuropsychology. 2015; 29(4): 561-570.

28. Gorenc-Mahmutaj L, Degen Ch, Wetzel P, Urbanowitsch N, Funke J, Schröder J. The Positivity Effect on the Intensity of Experienced Emotion and Memory Performance in Mild Cognitive Impairment and Dementia. Dement Geriatr Cogn Dis Extra. 2015; 5(2): 233-243. 